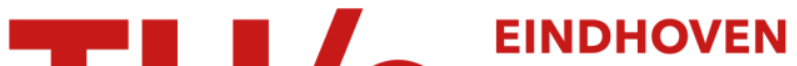 UNIVERSITY OF TECHNOLOGY
}

\section{Two-stage electrochemical synthesis of double molybdenum carbides}

Citation for published version (APA):

Dolmatov, V., Kuznetsov, S. A., Rebrov, E., \& Schouten, J. C. (2011). Two-stage electrochemical synthesis of double molybdenum carbides. Russian Metallurgy (Metally), 8, 767-773.

Document status and date:

Published: 01/01/2011

\section{Document Version:}

Publisher's PDF, also known as Version of Record (includes final page, issue and volume numbers)

\section{Please check the document version of this publication:}

- A submitted manuscript is the version of the article upon submission and before peer-review. There can be important differences between the submitted version and the official published version of record. People interested in the research are advised to contact the author for the final version of the publication, or visit the $\mathrm{DOI}$ to the publisher's website.

- The final author version and the galley proof are versions of the publication after peer review.

- The final published version features the final layout of the paper including the volume, issue and page numbers.

Link to publication

\section{General rights}

Copyright and moral rights for the publications made accessible in the public portal are retained by the authors and/or other copyright owners and it is a condition of accessing publications that users recognise and abide by the legal requirements associated with these rights.

- Users may download and print one copy of any publication from the public portal for the purpose of private study or research.

- You may not further distribute the material or use it for any profit-making activity or commercial gain

- You may freely distribute the URL identifying the publication in the public portal.

If the publication is distributed under the terms of Article $25 \mathrm{fa}$ of the Dutch Copyright Act, indicated by the "Taverne" license above, please follow below link for the End User Agreement:

www.tue.nl/taverne

Take down policy

If you believe that this document breaches copyright please contact us at:

openaccess@tue.nl

providing details and we will investigate your claim. 


\title{
Two-Stage Electrochemical Synthesis of Double Molybdenum Carbides
}

\author{
V. S. Dolmatov, S. A. Kuznetsov*, E. V. Rebrov, and J. C. Schouten \\ Tananaev Institute of Chemistry and Technology of Rare Elements and Mineral Raw Materials, Kola Science Centre \\ of Russian Academy of Sciences, Akademgorodok 26a, Apatity, Murmansk region, 184200 Russia \\ *e-mail: kuznet@chemy.kolasc.net.ru \\ Received August 9, 2010; in final form, October 2, 2010
}

\begin{abstract}
A new two-stage synthesis of double molybdenum and nickel carbides and high-activity and stable catalytic coatings of nickel-promoter molybdenum carbides in salt melts is developed. The first stage includes the formation of molybdenum-nickel alloys by an electrolytic method and currentless transfer in chloride melts. The second stage consists in the carbonization of the alloys in a chloride-carbonate melt under various synthesis conditions. The stabilities of the nickel-promoter catalytic systems are studied, and their catalytic activities in the back water-gas shift reaction are determined.
\end{abstract}

DOI: $10.1134 / \mathrm{S} 0036029511080052$

\section{INTRODUCTION}

The reforming of natural gas results in the formation of hydrogen with 10-12 vol \% carbon monoxide. Since CO is a poison for the proton-exchange membrane of a fuel element, the water-gas shift reaction

$$
\mathrm{CO}+\mathrm{H}_{2} \mathrm{O}=\mathrm{CO}_{2}+\mathrm{H}_{2}, \quad \Delta H^{0}=-41 \mathrm{~kJ} \mathrm{~mol}^{-1}
$$

is used to decrease its concentration to $1 \mathrm{vol} \%$ and to form an additional hydrogen volume. Since the watergas shift reaction (WGSR) is reversible and exothermic, a commercial $\mathrm{Cu} / \mathrm{ZnO} / \mathrm{Al}_{2} \mathrm{O}_{3}$ catalyst is now used for WGSR [1]. This catalyst has the following disadvantages. First, it occupies $70-80 \%$ of the catalyst system volume of a fuel processor. Second, copper oxidation makes this catalyst dangerously explosive. The use of precious metal-based catalysts is too expensive, and this type of catalysts undergoes degradation at a temperature above $573 \mathrm{~K}$.

Molybdenum carbide is a promising catalytic system that can substitute for the well-known catalysts [2-4].

The purpose of this work is to design next-generation high-activity and stable $\mathrm{Mo}_{2} \mathrm{C}$-based catalytic coatings for the water-gas shift reaction using electrochemical methods in salt melts. We are the first to apply two-stage electrochemical synthesis of double molybdenum and nickel carbides and nickel-promoter molybdenum carbides.

Various methods of synthesizing double molybdenum carbides are known. One of the most widely used method of producing double carbides is the joint electroreduction of molybdenum and nickel (cobalt) in chloride melts under $\mathrm{CO}_{2}$ pressure over a melt [5-7].
Another method of forming double molybdenum carbides consists in the carbonization of Mo and $\mathrm{Ni}$ alloys prepared in a carbonization gas (mixture of pure methane and hydrogen) flow at a temperature of $1273-1473 \mathrm{~K}$ for $100-150 \mathrm{~h}$ [8]. As a result of carbonization, $\mathrm{Ni}(\mathrm{Mo}, \mathrm{C})$ solid solutions with active carbon (graphite) on a plate surface form.

Bimetallic $\mathrm{Co}(\mathrm{Ni})-$ Mo carbides can also be synthesized due to the decomposition of precursors (metal-hexamethylenetetramine complexes) in an inert atmosphere $[9,10]$. This is a simple one-stage method of the formation of double $\mathrm{Co}_{3} \mathrm{Mo}_{3} \mathrm{C}$ and $\mathrm{Co}_{6} \mathrm{Mo}_{6} \mathrm{C}$ carbides [11]. In [12], the $\mathrm{Co}_{x} \mathrm{Mo}_{1-x}$ oxides prepared from aqueous solutions of cobalt nitrate and ammonium heptamolybdate were carbonized in a flow of pure methane and hydrogen $\left(20 \% \mathrm{CH}_{4} / \mathrm{H}_{2}\right.$ mixture) to form double carbides.

\section{EXPERIMENTAL}

\section{Two-Stage Electrochemical Synthesis of Double Carbides}

The salts were prepared as follows: they were mixed in the required quantities and loaded in a glass-carbon SU-2000 crucible, which was placed in a hermetically closed retort made of a stainless steel. This retort was pumped out to a residual pressure of $0.7 \mathrm{~Pa}$ first at room temperature and then upon steplike heating to $473 \mathrm{~K}$.

The temperature was measured with a Termodat17E3 temperature controller. The retort was filled with an inert gas (high-purity argon, $<3$ ppm $\mathrm{H}_{2} \mathrm{O}$ and $<2 \mathrm{ppm} \mathrm{O}_{2}$ ). Molybdenum plates located on current leads were immersed in a molten electrolyte through 
Table 1. Phase compositions of the products of carbonization of molybdenum-nickel allpoys

\begin{tabular}{|c|c|c|c|c|}
\hline \multicolumn{2}{|c|}{ Alloy formation conditions } & $\begin{array}{l}\text { Carbide formation } \\
\text { conditions }\end{array}$ & Phase composition & $\exp \#$ \\
\hline $\begin{array}{l}\text { Melt } \\
\mathrm{NaCl}-\mathrm{KCl}-\mathrm{NiCl}_{2}-\mathrm{Ni}, 1123 \mathrm{~K}\end{array}$ & $\begin{array}{l}\text { currentless, } 1 \mathrm{~h} \\
\text { electrolysis, } \\
i_{\mathrm{c}}=5 \mathrm{~mA} / \mathrm{cm}^{2}, 1 \mathrm{~h}\end{array}$ & $\begin{array}{l}923 \mathrm{~K}, 0.5 \mathrm{~h} \\
\\
973 \mathrm{~K}, 1 \mathrm{~h} \\
1023 \mathrm{~K}, 3 \mathrm{~h} \\
1123 \mathrm{~K}, 5 \mathrm{~h} \\
923 \mathrm{~K}, 0.5 \mathrm{~h} \\
973 \mathrm{~K}, 1 \mathrm{~h} \\
1023 \mathrm{~K}, 3 \mathrm{~h} \\
1123 \mathrm{~K}, 5 \mathrm{~h}\end{array}$ & $\begin{array}{l}\mathrm{Mo}, \mathrm{Ni}, \mathrm{Ni}_{3} \mathrm{Mo}_{3} \mathrm{C}, \\
\mathrm{Mo}_{0.25} \mathrm{Ni}_{0.75}, \mathrm{MoC} \\
\mathrm{Mo}, \mathrm{Ni}, \mathrm{Mo}_{2} \mathrm{C}, \mathrm{Ni}_{3} \mathrm{Mo}_{3} \mathrm{C} \\
\mathrm{Mo}, \mathrm{Ni}, \mathrm{Mo}_{2} \mathrm{C} \\
\mathrm{Mo}{ }_{2} \mathrm{C}, \mathrm{Mo}, \mathrm{Ni}, \beta-\mathrm{NiMoO}_{4} \\
\mathrm{Mo}, \mathrm{Ni} \\
\mathrm{Mo}, \mathrm{Ni}, \mathrm{Mo}_{2} \mathrm{C} \\
\mathrm{Mo}_{2} \mathrm{C}, \mathrm{Mo}, \mathrm{Ni}, \beta-\mathrm{NiMoO}_{4} \\
\mathrm{Mo}, \mathrm{Ni}, \mathrm{NiC}, \mathrm{Mo}_{2} \mathrm{C}\end{array}$ & $\begin{array}{l}\text { A } \\
\mathbf{B} \\
\text { C }\end{array}$ \\
\hline
\end{tabular}

special holes in the retort. We used a bulk anode made of a disperse metallic nickel powder.

During investigations, we chose the following two versions of preparing molybdenum and nickel alloys: electrolysis at a cathode current density of $5 \mathrm{~mA} / \mathrm{cm}^{2}$ in an $\mathrm{NaCl}-\mathrm{KCl}-\mathrm{NiCl}_{2}-\mathrm{Ni}$ melt (anode is metallic nickel), at a temperature of $1123 \mathrm{~K}$, and a process time of $1 \mathrm{~h}$ and currentless transfer in an $\mathrm{NaCl}-\mathrm{KCl}-$ $\mathrm{NiCl}_{2}-\mathrm{Ni}$ melt at the same temperature and time.

The $I-V$ characteristics were measured at a potential sweep speed varied from $5 \times 10^{-3}$ to $2.0 \mathrm{~V} / \mathrm{s}$ in the temperature range $973-1123 \mathrm{~K}$. Cyclic $I-V$ characteristics were recorded with molybdenum and glasscarbon working electrodes $0.5-2.0 \mathrm{~mm}$ in diameter with respect to a platinum wire, which was used as a reference $\mathrm{Pt}-\mathrm{PtO}_{x}-\mathrm{O}^{2-}$ quasi-electrode, and a reference $\mathrm{Ag} / \mathrm{NaCl}-\mathrm{KCl}-\mathrm{AgCl}(2 \mathrm{wt} \%)$ electrode. The glass-carbon crucible served as an auxiliary electrode.

The prepared molybdenum and nickel alloys were carbonized under various conditions. Carbonization was performed by electrolysis in an equimolar mixture of sodium and potassium chlorides containing carbonate ions ( $5 \mathrm{wt} \% \mathrm{Li}_{2} \mathrm{CO}_{3}$ ) during cathode polarization of a sample at a current density of $5 \mathrm{~mA} / \mathrm{cm}^{2}$. The other process parameters, namely, the electrolysis time and temperature are given in Table 1.

\section{Catalytic Activity of Double Molybdenum and Nickel Carbides and Nickel-Promoter Molybdenum Carbides}

We performed three series of experiments to study the catalytic activity of double molybdenum and nickel carbides and nickel-promoter molybdenum carbides (Table 1; series A, B, C).

We investigated the back water-gas shift reaction using a set of five $40 \times 10 \times 0.1-\mathrm{mm}$ coated plates. The initial area of the set was approximately $40 \mathrm{~cm}^{2}$. This set was placed into a glass reactor through which gases of certain compositions passed. At the exit from the reactor, the gas compositions were subjected to on-line analysis with a Varian 3800 chromatograph equipped with a thermal conductivity detector.
The samples were preliminarily processed a flow of a gas mixture of hydrogen (50 vol \%) and helium (50 vol \%) upon gradual heating to $673 \mathrm{~K}$ at a rate of $1 \mathrm{~K} / \mathrm{min}$.

The catalytic activity and the reaction order were determined at atmospheric pressure. Carbon dioxide, hydrogen, and helium were used as inlet gases; their ratio was changed as a function of experimental conditions; and the total pressure in all experiments was constant (1 atm). A change in the atmospheric pressure was taken into account in experiments. The temperature inside the reactor was varied from 473 to $598 \mathrm{~K}$. The hydrogen pressure was excessive, since the reaction is controlled by a carbon dioxide flow and the $\mathrm{CO}_{2}$ partial pressure was changed from 300 to $1200 \mathrm{~Pa}$.

\section{RESULTS AND DISCUSSION \\ Two-Stage Electrochemical Synthesis of Double Carbides}

Molybdenum-nickel alloys. The currentless process can be described as a process whose driving force is represented by an alloy formation reaction [13]. When metallic nickel interacts with its salt $\left(\mathrm{NiCl}_{2}\right)$, nickel cations with a lower oxidation state $[14,15]$,

$$
\mathrm{Ni}+\mathrm{Ni}^{2+} \leftrightarrow 2 \mathrm{Ni}^{+} .
$$

These cations diffuse through the melt and disproportionate on the surface of a molybdenum plate,

$$
2 \mathrm{Ni}^{+}+\mathrm{Mo} \leftrightarrow \mathrm{Ni}(\mathrm{Mo})+\mathrm{Ni}^{2+} .
$$

The disproportionation is accompanied by the formation of an alloy and nickel cations with the degree of oxidation of $+2 . \mathrm{Ni}^{2+}$ cations again interact with metallic nickel, the process forms a cycle, and the general reaction can be represented as

$$
\mathrm{Ni}+\mathrm{Mo} \leftrightarrow \mathrm{Ni}(\mathrm{Mo}) \text {. }
$$

As follows from X-ray diffraction data, $\mathrm{MoNi}$ and $\mathrm{MoNi}_{4}$ alloys form on the surface of molybdenum plates during both currentless transfer and electrolysis. The alloy formation leads to the "loosening" of the molybdenum substrate surface, which increases the 


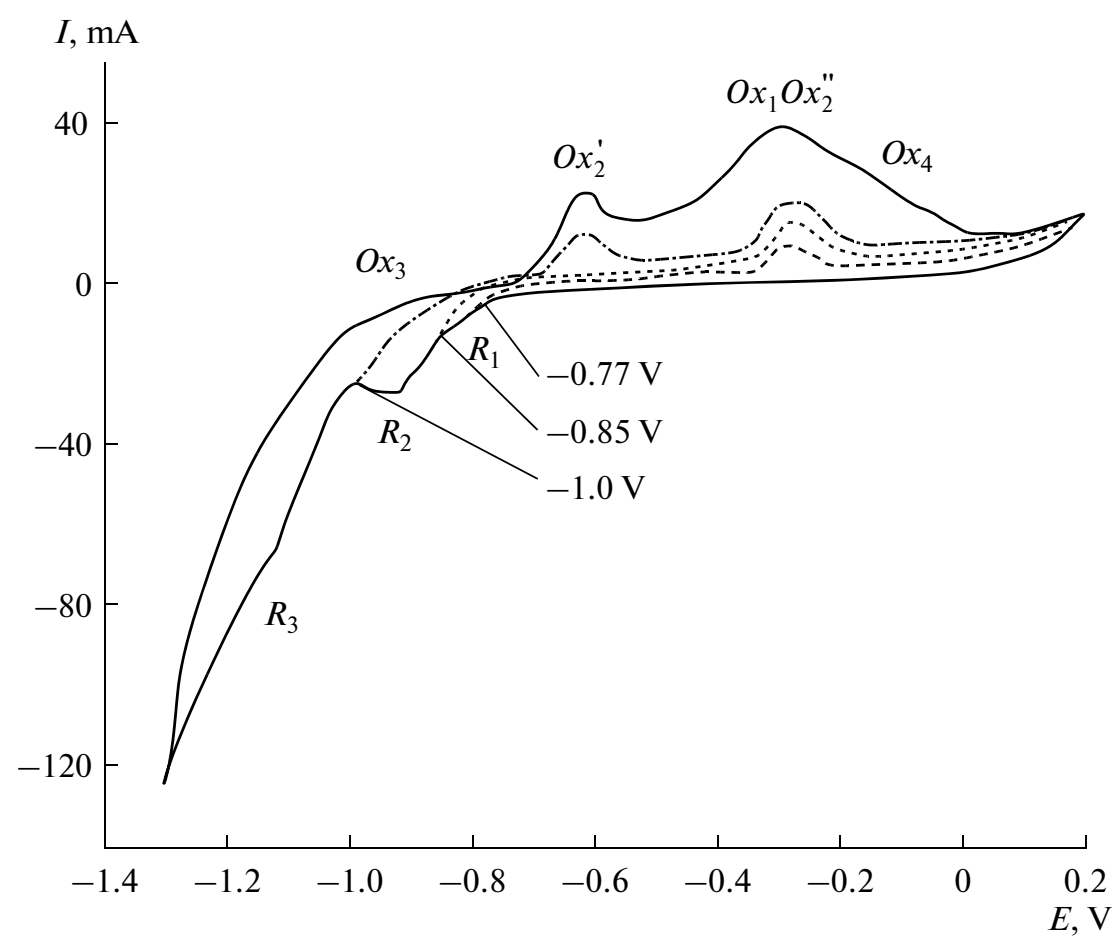

Fig. 1. Cyclic $I-V$ characteristics for an molybdenum electrode in an $\mathrm{NaCl}-\mathrm{KCl}-\mathrm{Li}_{2} \mathrm{CO}_{3}$ melt at various reverve potentials. The electrode area is $0.238 \mathrm{~cm}^{2}$, the polarization rate is $0.1 \mathrm{~V} / \mathrm{s}, T=1023 \mathrm{~K}$, and $C_{\mathrm{Li}_{2} \mathrm{CO}_{3}}=2.37 \times 10^{-4} \mathrm{~mol} / \mathrm{cm}^{2}$. The reference electrode is made of platinum.

specific surface area of the samples during carbonization.

Carbonization of molybdenum and molybdenumnickel alloys. Figure 1 shows the cyclic $I-V$ characteristics recorded at various reverse potentials of a molybdenum electrode in a chloride-carbonate $\mathrm{NaCl}-$ $\mathrm{KCl}-\mathrm{Li}_{2} \mathrm{CO}_{3}$ melt. These $I-V$ characteristics have three cathode waves $\left(R_{1}, R_{2}, R_{3}\right)$ and four electrooxidation peaks $\left(O x_{1}, O x_{2}^{\prime}, O x_{2}^{\prime \prime}, O x_{3}\right)$. The wave $R_{1}$ height decreases monotonically with increasing polarization rate and almost vanishes at a polarization rate of $1.0 \mathrm{~V} / \mathrm{s}$. At the potential corresponding to wave $R_{1}$, we performed potentiostatic electrolysis on the molybdenum electrode to form $\mathrm{Mo}_{2} \mathrm{C}$.

The electrooxidation $R_{1}$ current density is very low, which is likely to be caused by a low concentration of carbon-containing particles. Wave $R_{1}$ can correspond to the reduction of carbon dioxide, since the solubility of $\mathrm{CO}_{2}$ in an $\mathrm{NaCl}-\mathrm{KCl}$ melt at the given temperature is $(6-8) \times 10^{-8} \mathrm{~mol} / \mathrm{cm}^{3}$ and the electrode process can be described by the following reaction

$$
\mathrm{CO}_{2}+4 e^{-}+2 \mathrm{Mo} \rightarrow \mathrm{Mo}_{2} \mathrm{C}+2 \mathrm{O}^{2-} \text {. }
$$

In the presence of a carbonate ion, the chemical reaction

$$
\mathrm{CO}_{3}^{2-} \leftrightarrow \mathrm{CO}_{2}+\mathrm{O}^{2-} .
$$

precedes reaction (5).
The use of reverse at the potentials corresponding to wave $R_{1}(-0.77 \mathrm{~V}$ with respect to the platinum reference quasi-electrode) is accompanied by oxidation wave $O x_{1}$ corresponding to the dissolution of $\mathrm{Mo}_{2} \mathrm{C}$. The reverse from the base of wave $R_{2}(-0.850 \mathrm{~V})$ does not cause a new oxidation wave, and the peak $O x_{1}$ height increases. This behavior means that only the $\mathrm{Mo}_{2} \mathrm{C}$ phase forms on the molybdenum electrode in the cathode half-cycle. Waves $O x_{2}^{\prime \prime}$ and $O x_{2}^{\prime}$ have the same potential, which corresponds to the dissolution of $\mathrm{Mo}_{2} \mathrm{C}$. The $\mathrm{MoC}$ phase forms upon a potential shift from $-0.887 \mathrm{~V}$ toward a negative region, and peak $O x_{2}^{\prime}$ in the anode half-cycle corresponds to the dissolution of MoC. Therefore, the electrode processes corresponding to wave $R_{2}$ can be described by the following reactions [2]:

$$
\begin{gathered}
\mathrm{CO}_{3}^{2-}+4 e^{-}+2 \mathrm{Mo} \rightarrow \mathrm{Mo}_{2} \mathrm{C}+3 \mathrm{O}^{2-}, \\
\mathrm{CO}_{3}^{2-}+4 e^{-}+\mathrm{Mo} \rightarrow \mathrm{MoC}+3 \mathrm{O}^{2-} .
\end{gathered}
$$

Waves $R_{3}$ and $O x_{3}$ correspond to the discharge of alkali metal cations at the molybdenum cathode and the molybdenum carbides having formed on the electrode and to the dissolution of alkali metals, respectively. Shoulder $O x_{4}$ in the $I-V$ characteristics in Fig. 1 reflects the oxidation of oxide ions on the molybdenum surface. 


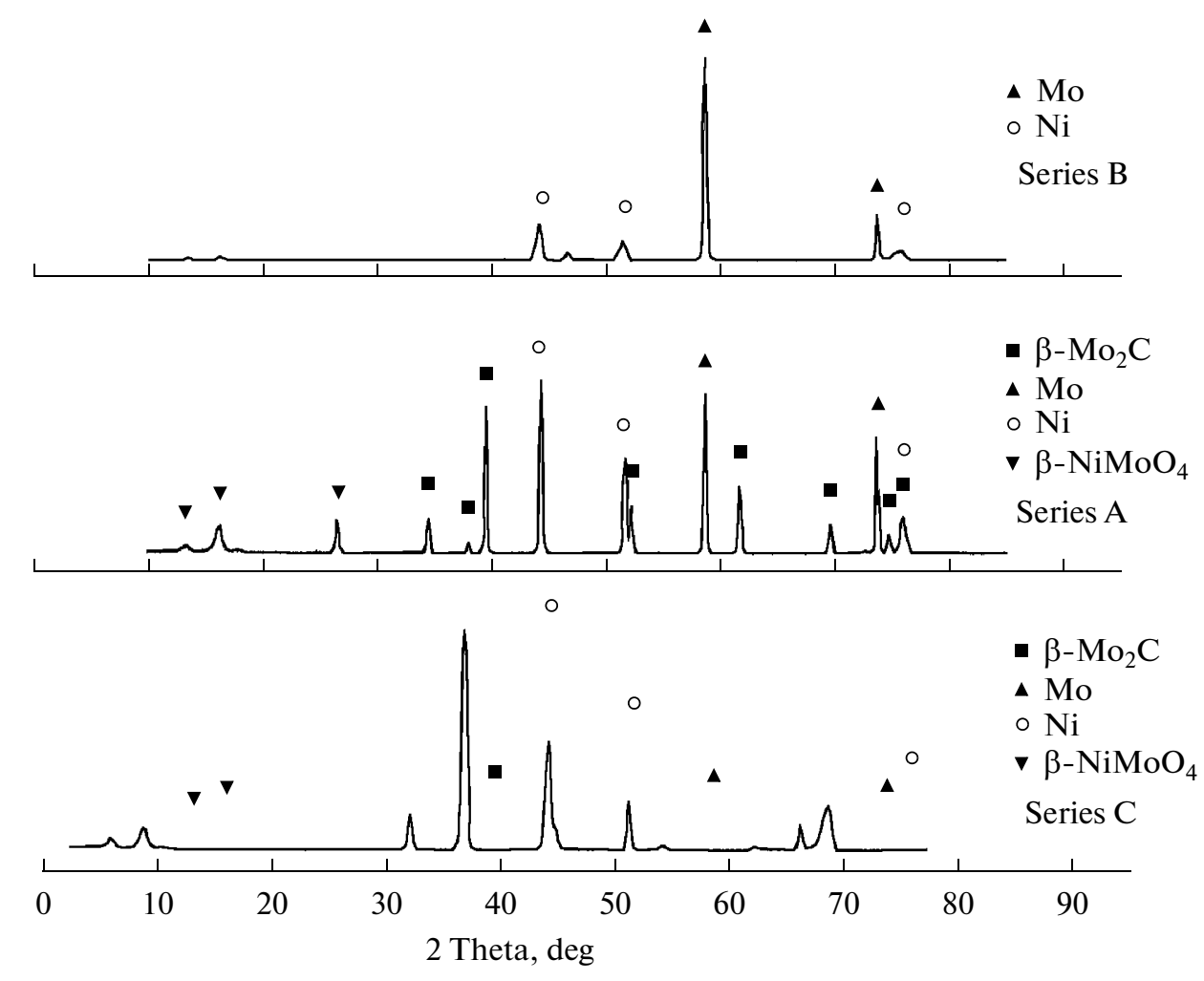

Fig. 2. X-ray diffraction patterns of the coatings produced in series A, B, and C.

Table 1 gives the products of the carbonization of molybdenum - nickel alloys synthesized under various conditions. The optimum carbonization conditions lead to the formation of $\mathrm{Mo}_{2} \mathrm{C}$ and double carbides rather than MoC, since it has a low catalytic activity. Figure 2 shows the X-ray diffraction patterns of the coatings produced in series $\mathrm{A}, \mathrm{B}$, and $\mathrm{C}$ experiments, and Fig. 3 shows a micrograph of the surface of one of the series A samples.

\section{Catalytic Activity of Double Molybdenum and Nickel Carbides and Nickel-Promoter Molybdenum Carbides}

We determined the catalytic activities of the samples of series A, B, and C. Table 2 presents the following data for determining the catalytic activities of the synthesized samples: conversion of carbon dioxide $\left(X_{\mathrm{CO}_{2}}\right)$, selectivity $(S)$, and the yield of the products of the back WGSR $(Y)$. We found that series A has the maximum catalytic activity.

Conversion $X_{\mathrm{CO}_{2}}$ is the ratio of the concentration of reacted $\mathrm{CO}_{2}$ to the initial $\mathrm{CO}_{2}$ concentration, i.e., the degree of transformation of $\mathrm{CO}_{2}$ into the products of the reaction

$$
X_{\mathrm{CO}_{2}}=\frac{C_{\mathrm{CO}_{2}}^{0}-C_{\mathrm{CO}_{2}}}{C_{\mathrm{CO}_{2}}^{0}}
$$

where $C_{\mathrm{CO}_{2}}^{0}$ is the initial $\mathrm{CO}_{2}$ concentration and $C_{\mathrm{CO}_{2}}$ is the final $\mathrm{CO}_{2}$ concentration.

Selectivity $S_{\mathrm{CH}_{4}}$ or $S_{\mathrm{CO}}$ is a dimensionless quantity, i.e., part of unity, where unity determines the carbon material balance: if $1 \mathrm{~mol} \mathrm{CO}_{2}$ enters into the reaction, we have $S_{\mathrm{CH}_{4}}+S_{\mathrm{CO}}=1$. The selectivities were calculated by the formulas:

$$
S_{\mathrm{CH}_{4}}=\frac{C_{\mathrm{CH}_{4}}}{C_{\mathrm{CO}_{2}}^{0}-c_{\mathrm{CO}_{2}}}, \quad S_{\mathrm{CO}}=\frac{C_{\mathrm{CO}}}{C_{\mathrm{CO}_{2}}^{0}-C_{\mathrm{CO}_{2}}} .
$$

The products of the back water-gas shift reaction were found to be carbon monoxide, water, and methane. Thus, the back WGSR

$$
\mathrm{CO}_{2}+\mathrm{H}_{2}=\mathrm{CO}+\mathrm{H}_{2} \mathrm{O}, \quad \Delta H^{0}=+41 \mathrm{~kJ} \mathrm{~mol}^{-1}
$$

is accompanied by the formation of methane,

$$
\begin{aligned}
& \mathrm{CO}_{2}+4 \mathrm{H}_{2}=\mathrm{CH}_{4}+2 \mathrm{H}_{2} \mathrm{O}, \Delta H^{0}=-114 \mathrm{~kJ} \mathrm{~mol}^{-1}, \\
& \mathrm{CO}+3 \mathrm{H}_{2}=\mathrm{CH}_{4}+\mathrm{H}_{2} \mathrm{O}, \Delta H^{0}=-206 \mathrm{~kJ} \mathrm{~mol}^{-1}, \\
& 2 \mathrm{CO}+2 \mathrm{H}_{2}=\mathrm{CH}_{4}+\mathrm{CO}_{2}, \Delta H^{0}=-247 \mathrm{~kJ} \mathrm{~mol}^{-1} .
\end{aligned}
$$

It was shown that the back WGSR is a first-order reaction, the activation energy in the Arrhenius equation

$$
k=A e^{-E_{\mathrm{a}} / R T}
$$




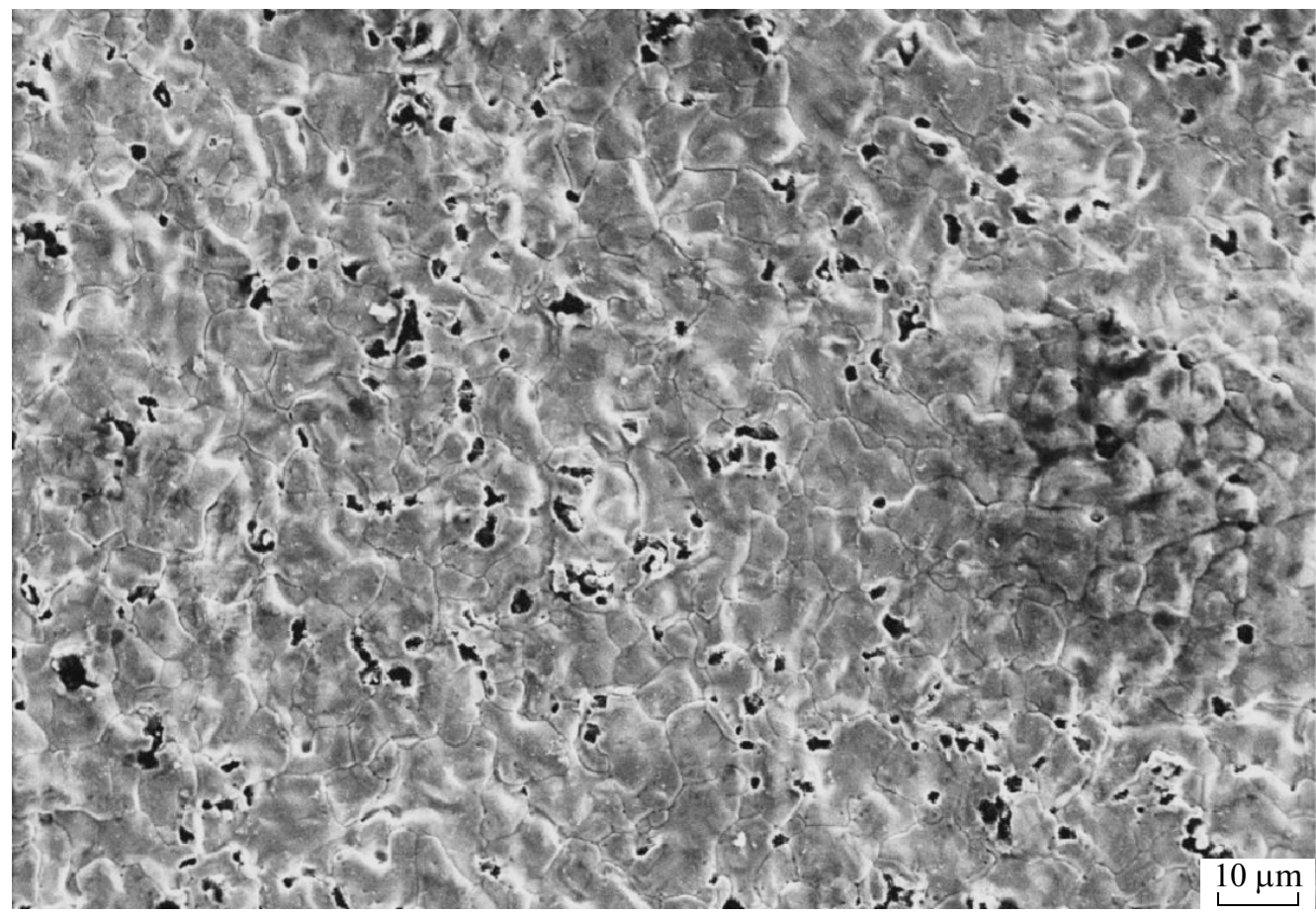

Fig. 3. Micrograph of a molybdenum-nickel alloy produced by currentless transfer in an $\mathrm{NaCl}-\mathrm{KCl}-\mathrm{NiCl}{ }_{2}-\mathrm{Ni}$ melt at $1123 \mathrm{~K}$ for $1 \mathrm{~h}$ followed by carbonization in an $\mathrm{NaCl}-\mathrm{KCl}-\mathrm{Li}_{2} \mathrm{CO}_{3}$ melt at $i_{\mathrm{c}}=5 \mathrm{~mA} / \mathrm{cm}^{2}$ and $T=1123 \mathrm{~K}$ for $5 \mathrm{~h}$ (series A).

is $E_{\mathrm{a}}=42 \mathrm{~kJ} / \mathrm{mol}$, the reaction constant is $k=4.51 \times$ $10^{-11} \mathrm{~s}^{-1}($ at $523 \mathrm{~K})$, and the preexponential factor is $7.62 \times 10^{-7} \mathrm{~s}^{-1}$.

The coatings of the nickel-promoter molybdenum carbides are stable at least for $30 \mathrm{~h}$. After measuring the catalytic activity, the phase composition of these coatings is unchanged. We also found no changes in the morphology of the nickel-promoter molybdenum carbides after their catalytic activity was measured.

The conversion of carbon dioxide on the synthesized catalysts is an order of magnitude higher than the conversion of $\mathrm{CO}_{2}$ on molybdenum carbide $[2,16]$. Since methane formation is an undesirable process in WGSR, it is necessary to check the probability of methane formation in the forward water-gas shift reaction. We assume that the synthesized coatings can also be active catalysts for the forward reaction.

Since metallic nickel is a catalyst for the formation of carbon due to the decomposition of methane and the disproportionation of $\mathrm{CO}$, these processes can result in catalyst deactivation and the clogging of the proton-exchange membrane of a fuel element by elementary carbon,

$$
\begin{aligned}
\mathrm{CH}_{4} & =\mathrm{C}_{(S)}+2 \mathrm{H}_{2}, \\
2 \mathrm{CO} & =\mathrm{C}_{(S)}+\mathrm{CO}_{2} .
\end{aligned}
$$

In our case, however, we did not detect carbon formation during the back WGSR.

Apparently, the use of double molybdenum and cobalt carbides and nickel-promoter molybdenum carbides in the forward and back water-gas shift reac-

Table 2. Temperature dependences of the conversion of $\mathrm{CO}_{2}$, the selectivity, and the yield of the products of the reverse vapor conversion reaction

\begin{tabular}{c|c|c|c|c|c|c}
\hline$T, \mathrm{~K}$ & $X_{\mathrm{CO}_{2}}$ & $S_{\mathrm{CH}_{4}}$ & $S_{\mathrm{CO}}$ & $S_{\mathrm{CH}_{4}} / S_{\mathrm{CO}}$ & $Y_{\mathrm{CH}_{4}}$ & $Y_{\mathrm{CO}}$ \\
\hline 483 & 0.0564 & 0.334 & 0.675 & 0.49 & 0.01885 & 0.03809 \\
493 & 0.0669 & 0.316 & 0.740 & 0.43 & 0.02114 & 0.04951 \\
503 & 0.0823 & 0.328 & 0.760 & 0.43 & 0.02699 & 0.06254 \\
513 & 0.0974 & 0.389 & 0.801 & 0.49 & 0.03787 & 0.07799 \\
523 & 0.1283 & 0.371 & 0.660 & 0.56 & 0.04760 & 0.08467 \\
\hline
\end{tabular}



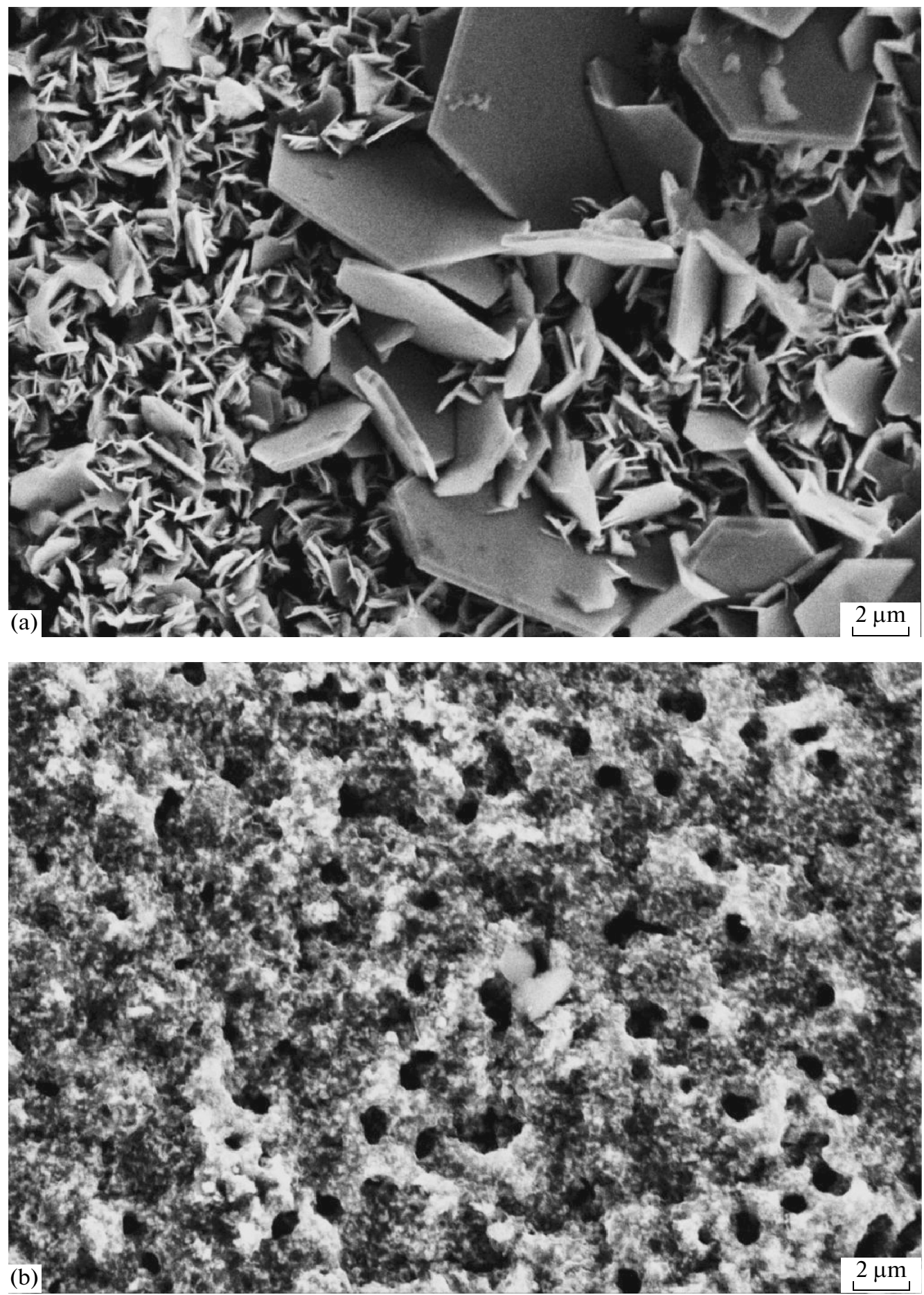

Fig. 4. (a) Molybdenum-cobalt alloy produced by currentless transfer in an $\mathrm{NaCl}-\mathrm{KCl}-\mathrm{CoCl}_{2}-\mathrm{Co}$ melt at $1123 \mathrm{~K}$ for $1 \mathrm{~h}$ followed by carbonization in an NaCl- KCl-CoCl $2-\mathrm{Co}$ melt at $i_{\mathrm{c}}=5 \mathrm{~mA} / \mathrm{cm}^{2}$ and $T=1123 \mathrm{~K}$ and (b) molybdenum-cobalt alloy produced by electrolysis in an $\mathrm{NaCl}-\mathrm{KCl}-\mathrm{CoCl}_{2}-\mathrm{Co}$ melt at $i_{\mathrm{c}}=5 \mathrm{~mA} / \mathrm{cm}^{2}$ and $1123 \mathrm{~K}$ for $1 \mathrm{~h}$ followed by carbonization in an $\mathrm{NaCl}-\mathrm{KCl}-\mathrm{Li}_{2} \mathrm{CO}_{3}$ melt at $i_{\mathrm{c}}=5 \mathrm{~mA} / \mathrm{cm}^{2}$ and $T=1123 \mathrm{~K}$ for $5 \mathrm{~h}$.

tion reaction makes it possible to avoid methane formation. Therefore, we will study the catalytic activities of double Mo and Co carbides and nickel-promoter molybdenum carbides. The preliminary results of syn- thesizing these carbides demonstrate that their surface is much more developed as compared to the nickelcontaining compositions (Fig. 4). The products of carbonization of the molybdenum and cobalt alloys are 
carbides $\quad \mathrm{Co}_{6} \mathrm{Mo}_{6} \mathrm{C}_{2}, \quad \mathrm{Co}_{6} \mathrm{Mo}_{6} \mathrm{C}, \quad \mathrm{Co}_{3} \mathrm{Mo}_{3} \mathrm{C}$, and cobalt-promoter $\mathrm{Mo}_{2} \mathrm{C}$ depending on the synthesis conditions.

\section{CONCLUSIONS}

We proposed a new two-stage method for synthesizing double molybdenum and nickel carbides and nickel-promoter molybdenum carbides. It consists in electrochemical synthesis of molybdenum and nickel alloys in a chloride melt followed by carbonization in a chloride-carbonate melt.

\section{ACKNOWLEDGMENTS}

This work was supported by the Netherlands Organization for Scientific Research (NWO) (project no. 047.017.029) and the Russian Foundation for Basic Research (project no. 047.011.2005.016).

\section{REFERENCES}

1. N. E. Amadeo and M. A. Laborde, "Hydrogen Production from the Low-Temperature Water-Gas Shift Reaction: Kinetics and Simulation of the Industrial Reactor,” Int. J. Hydrogen Energ. 20 (12), 949-956 (1995).

2. S. A. Kuznetsov, A. R. Dubrovskiy, E. V. Rebrov, and J. C. Schouten, "Electrochemical Synthesis of $\mathrm{Mo}_{2} \mathrm{C}$ Catalytical Coatings for the Water-Gas Shift Reaction," Z. Naturforsch A 62, 647-654 (2007).

3. E. V. Rebrov, S. A. Kuznetsov, M. H. J. M. de Croon, and J. C. Schouten, "Study of the Water-Gas Shift Reaction on $\mathrm{Mo}_{2} \mathrm{C} / \mathrm{Mo}$ Catalytic Coatings for Application in Microstructured Fuel Processors," Catal. Today 125, 88-96 (2007).

4. A. R. Dubrovskiy, S. A. Kuznetsov, E. V. Rebrov, and J. C. Schouten, "Electrochemical Synthesis in the Molten Salts of Catalytic $\mathrm{Mo}_{2} \mathrm{C}$ Coatings for the Conversion of CO with Water Vapor," Kinet. Katal. 49 (4), 620-624 (2008).

5. Kh. B. Kushkhov, D. G. Supatashvili, V. I. Shapoval, I. A. Novoselova, and N. A. Gasviani, "Joint Electroreduction of a Molybdate Ion with Nickel and Cobalt Cations in Chloride Melts," Elektrokhimiya 26 (3), 300-304 (1990).
6. Kh. B. Kushkhov, D. G. Supatashvili, I. A. Novoselova, and V. I. Shapoval, "Joint Electroreduction of Various Ionic Forms of Tungsten with Nickel and Cobalt Cations in Halide Melts," Elektrokhimiya 26 (6), 720-723 (1990).

7. Kh. B. Kushkhov, V. I. Shapoval, and I. A. Novoselova, "Electrochemical Behavior of Carbon Dioxide at an Excess Pressure in the Equimolar Solution of Sodium and Potassium Chklorides," Elektrokhimiya 23 (7), 952-956 (1987).

8. M. Kikuchi, S. Takeda, M. Kajihara, and R. Tanaka, "Activity of Carbon in Nickel-Rich Ni-Mo and Ni-W Alloys," Metall. Mater. Trans. A 19, 645-650 (1988).

9. Sandra Chouzier, Pavel Afanasiev, Michel Vrinat, Tivadar Cseri, and Magalie Roy-Auberger, "One-Step Synthesis of Dispersed Bimetallic Carbides and Nitrides from Transition Metals Hexamethylenetetramine Complexes," J. Solid State Chem. 179 (11), 33143323 (2006).

10. Masatoshi Nagai, Amin Md. Zahidul, and Kenji Matsuda, "Nanostructured Nickel-Molybdenum Carbide Catalyst for Low-Temperature Water-Gas Shift Reaction," Appl. Catal. A, 313, 137-145 (2006).

11. Xiao-Hui Wang, Ming-Hui Zhang, Wei Li, and Ke-Yi Tao, "Synthesis and Characterization of Cobalt-Molybdenum Bimetallic Carbides Catalysts," Catal. Today 131, 111-117 (2008).

12. Masatoshi Nagai and Kenji Matsuda, "Low-Temperature Water-Gas Shift Reaction over Cobalt-Molybdenum Carbide Catalyst," J. Catal. 238, 489-496 (2006).

13. N. G. Ilyushchenko, A. I. Afinogenov, and N. I. Shchurov, Metal Interactions in Ionic Melts (Nauka, Moscow, 1991) [in Russian].

14. Yu. V. Baimakov and I. V. Tomskikh, "Solidification of a Transition Metal on a Cathode during Electrolysis of Its Chlorides (Nickel as an Example)," in Physical Chemistry and Electrochemistry of Molten Salts and Slags (Khimiya, Leningrad, 1968), pp. 52-64.

15. A. M. Potapov, "Electronic Absorption Spectra and Redox Potentials of the Dilute Solutions of Nickel and Chromium Chlorides in the Molten Chlorides of Alkali Metals," Extended Abstract of Cand. Sci. (Chem.) Dissertation, IE URO RAN, 1991.

16. J. Patt, D. J. Moon, C. Phillips, and L. Thompson, "Molybdenum Carbide Catalysts for Water-Gas Shift," Catal. Lett. 65, 193-195 (2000). 